\title{
PLURIATIVIDADE EM UMA COMUNIDADE PESQUEIRA NO LITORAL LESTE DO CEARÁ: estimativas e desdobramentos para a gestão dos recursos ambientais
}

\author{
PLURIACTIVITY IN A FISHING COMMUNITY ON CEARÁ'S \\ EASTERN COASTLINE: estimates and developments for the \\ management of environmental resources
}

\begin{abstract}
Leilane Oliveira Chaves
Universidade Federal do Ceara, Programa de Pós-graduação em Desenvolvimento e Meio Ambiente, Fortaleza, Ceará - Brasil leilane_chaves@hotmail.com

Christian Brannstrom Texas A\&M University, Departamento de Geografia, College Station, Texas, EUA cbrannst@geos.tamu.edu

Edson Vicente da Silva Universidade Federal do Ceará, Departamento de Geografia, Fortaleza, Ceará, Brasil cacauceara@gmail.com
\end{abstract}

\section{Resumo}

Os estudos sobre pluriatividade continuamente abordam as estruturas sociais e econômicas das famílias do meio rural em ambientes terrestres. No entanto, trabalhos de Sacco dos Anjos, et al. (2012); Santos (2015) e Santos e Brannstrom (2015) emergem na inclusão de usuários de recursos costeiros, os pescadores tradicionais, nas discussões sobre pluriatividade. Assim, o presente artigo analisa a pluriatividade em uma comunidade pesqueira no litoral leste do Ceará, com base na aplicação de 23 questionários com representantes do núcleo residencial. O estudo indica as principais modalidades da pluriatividade (famílias pesqueiras, famílias pluriativas e famílias não pesqueiras), mostrando que as atividades relacionadas aos recursos naturais, quando realizadas isoladamente, são insuficientes para a subsistência das famílias. Pensões e políticas sociais ajudam as famílias a manter a pluriatividade. O estudo colabora na ampliação das discussões acerca da pluriatividade em áreas costeiras e na análise das interferências de grandes projetos de desenvolvimento na pluriatividade, mostrando que a diversidade de atividades ocorre muito mais por necessidade do que por escolha do núcleo familiar, mas podem atenuar a pressão sobre o uso de recursos naturais e aumentar o controle das práticas tradicionais nesses ambientes, contribuindo para uma melhor planejamento e gestão dos territórios tradicionais.

Palavras-chave: Pluriatividade. Comunidade tradicional. Pesca. Litoral Leste do Ceará. Impactos. 


\begin{abstract}
Studies focusing on pluriactivity normally analyze social and economic structures among rural families using land-based resources. However, studies by Sacco dos Anjos et al. (2004; 2012); Santos (2015) and Santos and Brannstrom (2015) include coastal resource users such as traditional fishers in discussions about pluriactivity. Thus, the present article analyzes pluriactivity in a fishing community on Ceará's eastern coastline based on the application of 23 questionnaires with household representatives. The study indicates the main modalities of pluriactivity (fishing families, pluriactive families and non-fishing families), showing that activities related to natural resources, when carried out alone, are insufficient for the subsistence of families. Pensions and social polices help families maintain pluriactivity. The study contributes to broadening discussions on pluriactivity in coastal areas and to analyzing the interference of large development projects on pluriactivity, showing that diverse activities occur out of household necessity rather than choice, but can reduce pressure on the use of natural resources and increase the control of traditional practices in these environments, contributing to better planning and management of traditional territories.
\end{abstract}

Key words: Pluriactivity. Traditional community. Fishing. East Coastal of Ceará. Impacts.

\title{
Introdução
}

No espaço rural brasileiro, as estratégias de meios de vida representam um aspecto importante das famílias de pequenos agricultores (TERNOSKI; PERONDI, 2014). Apesar de pesquisas recentes sobre a relevância e problemas enfrentados pela agricultura familiar, ainda é diminuto o número de estudos que atestam a importância dos agricultores familiares "como atores sociais e percebam em sua capacidade de diversificação econômica e empreendedora, pistas para compreender o desenvolvimento rural e regional como um todo" (PERONDI; SCHNEIDER, 2012, p. 133). Ao direcionar um olhar para a pluriatividade, é possível compreender se sua existência está atrelada a necessidade ou a uma ação proativa das famílias. Por isso, a pluriatividade dever ser analisada como um fenômeno que se origina de processos sociais e econômicos, intrínsecos as unidades familiares, bem como da ação e reação direta das famílias que participam de forma efetiva desse processo, sendo conduzido com base no modo como ela é gerada pelos próprios grupos locais (SCHNEIDER, 2003).

Compreender como a pluriatividade ocorre em populações tradicionais é considerar a diversidade de meios de subsistência como uma característica importante da sobrevivência rural (ELLIS, 1999). Além de propiciar uma maior visibilidade e 
compreensão de seus modos de vida, a relevância de se observar a pluriatividade também se relaciona a uma melhor gestão dos recursos naturais. Para Ellis (1999), a diversidade de meios de subsistência proporciona a flexibilidade, resiliência e estabilidade, onde os sistemas diversificados são menos vulneráveis do que os não-diversificados. A pluriatividade pode até ser mais sustentável ao longo do tempo pela possibilidade de oferecer uma melhor resposta de adaptação a mudanças ambientais e econômicas. Vadjunec et al. (2016), esclarecem que um melhor conhecimento da pluriatividade de pequenos produtores rurais implica apoiar o uso sustentável dos recursos naturais, bem como adequar políticas públicas para reduzir as desigualdades econômicas e vulnerabilidade às mudanças climáticas e outros choques externos.

Na visão de Ellis (1999), os efeitos da diversificação podem colaborar para uma melhor gestão dos recursos ambientais já que ocorreria uma alternância de atividades incluindo as não agrícolas, havendo um melhor controle das práticas tradicionais realizadas nos ambientes naturais controlados pelas famílias. No Brasil, a pluriatividade ganha destaque segundo Schneider (2007), porque há um entendimento de sua potencialidade como forma de promover mecanismos sustentáveis de diversificação dos modos de vida possibilitando ampliar as condições de reprodução social e econômica.

Neste artigo, apresenta-se um estudo de caso desenvolvido na comunidade do Cumbe, no litoral leste cearense, com resultados obtidos a partir de questionários que procuraram definir os meios de vida dos moradores, num contexto de conflito com fazendas de camarão (QUEIROZ, et al., 2013) e parques eólicos (BROWN, 2011). A pluriatividade é uma prática comum entre os residentes do Cumbe, não só pela insuficiência de rendimentos, mas como uma necessidade diante da presença de grandes empreendimentos que limitam o acesso e comprometem a qualidade dos recursos naturais presentes no território. Analisou-se a pluriatividade com relação aos vínculos ao mercado, ao autoconsumo, à renda e aos deslocamentos espaciais devido aos empreendimentos. Entender melhor a pluriatividade é importante para obter uma análise mais precisa sobre os impactos das eólicas nas comunidades tradicionais (BRANNSTROM et al., 2017) e para entender melhor os processos de formação de identidade coletiva de comunidades “invisíveis” (LEROY; MEIRELES, 2013) e resistência de comunidades aos grandes empreendimentos. 
Pluriatividade em uma comunidade pesqueira no litoral Leste do Ceará: estimativas e desdobramentos para a gestão dos recursos ambientais
Leilane Oliveira Chaves

Christian Brannstrom Edson Vicente da Silva

\section{A pluriatividade na organização familiar rural}

As populações tradicionais em diversas localidades globais são vistas como grupos que desenvolviam atividades ligadas à sua subsistência com ocupações, que de forma geral estavam predominantemente ligadas ao campo (DFID, 1999). Atualmente, há um processo de transformação no espaço rural, com a expansão de atividades nãoagrícolas e a identificação de distintas formas de uso do espaço, proporcionando o estabelecimento de núcleos familiares pluriativos. Essa forma de organização é intitulada de pluriatividade e diz respeito a indivíduos do mesmo núcleo familiar que estão ligados por laços de parentesco e de consanguinidade, que não necessariamente residam na mesma residência, mas que em conjunto realizam distintas atividades dentro ou fora do domicílio (SCHNEIDER, 2003; 2007). Em algumas localidades do Brasil a pluriatividade ocorre por necessidade e não como alternativa. Esse cenário é manifesto em territórios tradicionais que estão em disputa pelo acesso a recursos naturais. Esses conflitos estão associados a diferentes formas de uso da terra, de um lado vista como oportunidade de gerar lucro e de outro, expressão da identidade de um grupo (ACSERALD, 2010; LEROY; MEIRELES, 2013).

Os estudos sobre pluriatividade são aplicados ao meio rural e terrestre brasileiro, tendo a agricultura como base para se pensar a pluriatividade, entretanto, Schneider (2003, p.117) esclarece que a pluriatividade igualmente pode ser considerada para a compreensão de outras formas familiares de produção:

[...] Quando se propõe estudar as formas familiares de organização do trabalho e da produção não se está imaginando que elas estejam restritas ao setor agrícola e ao espaço rural, pois existem várias outras atividades em que se pode observar essa configuração. $\mathrm{O}$ mesmo pode ser afirmado em relação à pluriatividade, que se apresenta como um fenômeno social relativamente novo e desconhecido no espaço rural, embora suas características há muito estejam presentes nas diversas formas de trabalho (precário ou não) exercidas no âmbito urbanoindustrial, pois, em essência, trata-se da combinação de mais de uma atividade ocupacional por pessoas que pertencem a uma mesma família (SCHNEIDER, 2003, p. 117).

Baseando-se nas ideias de Schneider sobre a existência de pluriatividade em outros grupos sociais, Cotrim e Miguel (2008) estabeleceram relações entre a pluriatividade e os pescadores artesanais ou tradicionais, chegando ao entendimento de 
que, assim como os camponeses, os pescadores artesanais diversificam suas atividades de pesca com atividades não-pesqueiras. Processamento do pescado, comercialização, prestação de serviços a terceiros, pequenos cultivos, criação de animais, etc. são atividades que permitem detectar nos pescadores comportamentos pluriativos que garantem múltiplas fontes de renda e a manutenção de suas estratégias de reprodução social. Santos e Brannstrom (2015) identificaram três tipos de atividade pesqueira no litoral baiano, onde a pluriatividade gira em torno de acesso a diferentes tipos de barcos, acesso ao mangue e a agricultura. Recursos financeiros e a divisão de trabalho por gênero influenciaram as formas e tipos específicos da pluriatividade observada na Reserva Extrativista de Cassurubá (SANTOS 2015; SANTOS; BRANNSTROM, 2015).

Do mesmo modo, encontra-se nos estudos de Sacco dos Anjos, et. al (2012), a pluriatividade sendo exercida entre grupos familiares da Colônia de Pescadores Z-13, em Pelotas, Rio Grande do Sul. Os autores identificaram que as famílias podiam ser segmentadas em três grandes categorias: famílias exclusivamente pesqueiros, famílias pluriativas de base pesqueira e famílias pluriativas de base não-pesqueira. Os maiores rendimentos não estavam associados exclusivamente a atividades pesqueiras e houve a interferência de agentes externos no desenvolvimento das atividades tradicionais.

Para Ellis (1999) e Vadjunec et al., (2016), os efeitos positivos da diversificação de renda e de fontes de autoconsumo diz respeito a sustentabilidade do modo de vida, aumento da capacidade de resistência diante de condições adversas, maior flexibilidade permitindo a substituição de atividades melhorando as condições de vida do agregado familiar. Porém, as desvantagens evidenciadas em alguns estudos empíricos incluem o aumento na desigualdade dos rendimentos entre os grupos familiares e o abandono ou estagnação das atividades agrícolas. Para esses estudos, em geral, os aspectos positivos da diversificação sobrepujam os negativos, contribuindo positivamente para a superação da pobreza, já que pode proporcionar formas mais autônomas de desenvolvimento local, ampliando as escolhas e opções de atividades diminuindo a dependência das populações locais ao uso de um único recurso e a recursos controlados por agentes externos.

É importante evidenciar que a presença de grandes epreendimentos colabora na existência da pluriatividade e que ela é praticada não como escolha dos grupos familiares, mas como um necessidade para manutenção de seu modo de vida. Essa é o contexto em 
Pluriatividade em uma comunidade pesqueira no litoral Leste do Ceará: estimativas e desdobramentos para a gestão dos recursos ambientais
Leilane Oliveira Chaves Christian Brannstrom Edson Vicente da Silva

que se encontra as famílias que integram a comunidade do Cumbe, área de estudo do presente artigo.

\section{Caracterização da área de estudo}

A pesquisa de campo concentrou-se na comunidade do Cumbe, município de Aracati, litoral leste do Ceará (Figura 1). No Cumbe, a geografia da localidade possibilita o desenvolvimento de diferentes atividades nos diversos ambientes naturais. Pesca, mariscagem, criação de animais, cultivos de subsistência e a confecção de artesanato, integram as principais atividades de grande parte dos participantes da pesquisa.

Figura 1: Localização geográfica do Cumbe, litoral leste do estado do Ceará.

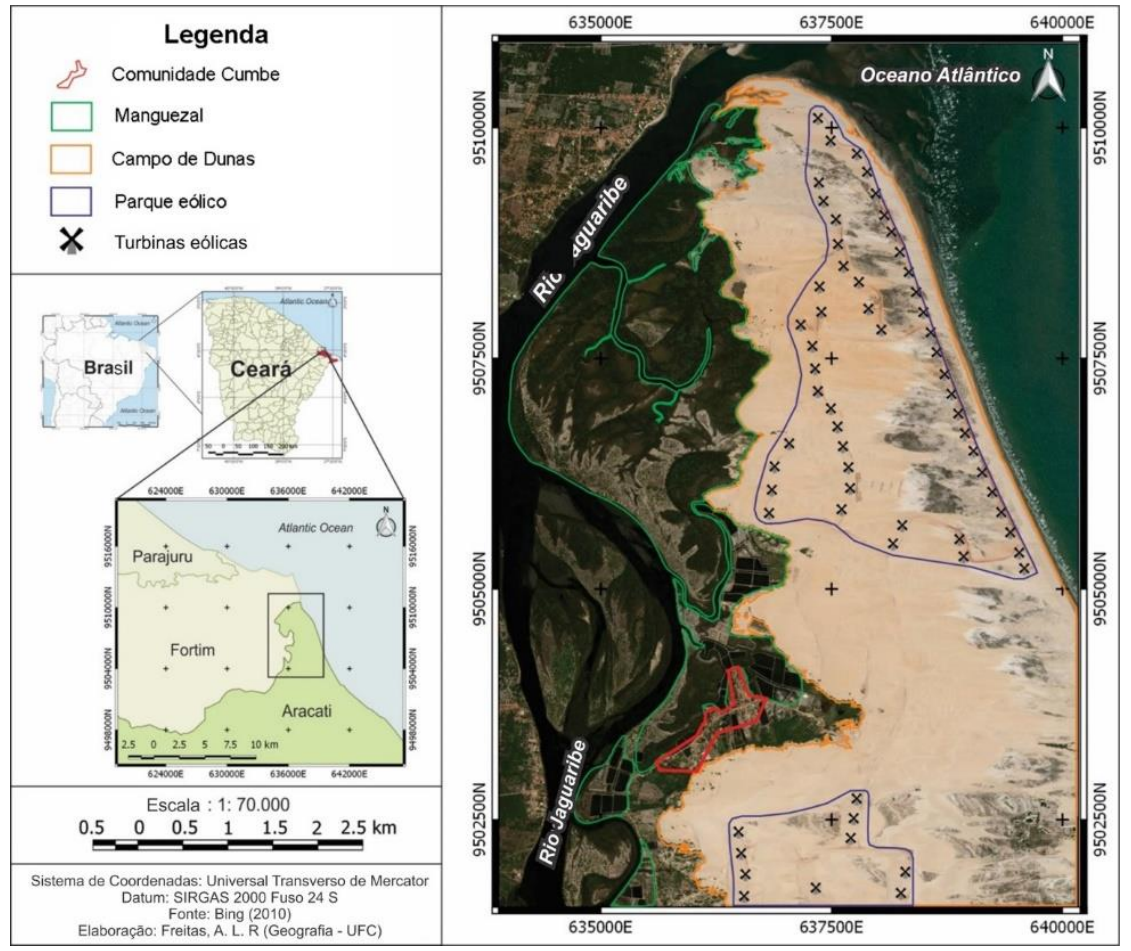

Fonte: Leilane Oliveira Chaves (2017).

Em 2010, algumas famílias da comunidade se autodefiniram como quilombolas resultando na criação da Associação Quilombola do Cumbe. Até junho de 2018, 86 famílias integram a Associação Quilombola e o território encontrava-se em processo de demarcação das terras junto ao Instituto de Colonização e Reforma Agrária (INCRA). A instalação de fazendas de camarão, em 1998, em certos setores do manguezal e de um parque eólico, construído em 2008 no campos de dunas, tem retardado a finalização do 
processo. Esses empreendimetnos ocupam parte do território ocasionando limitações de acesso aos recursos naturais, destruição de locais de pesca e de cultivos e alterações na qualidade desses ambientes (BROWN, 2011; CHAVES, et al., 2018).

A instalação dos empreendimentos transformou o território e a vida das famílias do Cumbe. Algumas famílias relataram que a vida antes das fazendas de camarão e do parque eólico era diferente. Cinco famílias empregaram o uso da frase "era livre" para se referir a forma como usufruíam do território. Como indica a entrevistada 7 (19 anos, 10/09/2016) "a gente era livre, ele [parque eólico] trouxe tipo um limite. A gente não tem mais aquela liberdade de ir e vir. Agora se a gente quiser não tem mais". O entrevistado 16 (33 anos, 12/08/2016) também estabelece essa associação “era uma área que era livre, era nossa né, e agora tá limitada. Você não pode ir ali, você não pode ir acolá, as vezes é perigoso tem canto por aí que tem fiação tá arriscado morrer alguém, porque quando estoura uma fiação ali ninguém sabe onde é”. A ausência de liberdade também foi sentida com as ações dos empreendedores da carcinicultura, como relata o entrevistado 14 (34 anos, 10/09/2016) ao expor que os caminhos usados para acesso ao manguezal são vigiados diariamente.

"Eu sei que houve até uns caminhos, caminhos antigos que foi tirado essa liberdade nossa. Tinha uns caminhos antigos que você não conhece hoje por causa dos paredões [tanques de camarão]. Nois podiamo passar de bicicleta e hoje passa em cima do paredaozinho, porque é vigia dia e noite. Tem vigia dia e noite. Você tá lá de sentinela $24 \mathrm{hs}$ por dia. Quem passou foi beltrano. Quem passou foi ciclano. Então tirou bastante essa liberdade".

A ausência de liberdade relatada pelas famílias não se limita apenas as modificações nas atividades de subsistência, mas também tangem as diversas dimensões de sua existência vivenciadas nesse território. Ao buscar compreender e explicar as principais formas de sustento familiar (recursos, renda e atividades) e os efeitos da instalação da carcinicultura e do parque eólico sobre os meios de vida dos grupos familiares, optou-se pela aplicação do questionário junto a população local. A construção do questionário se apoiou na base conceitual de meios de vida (BEBBINGTON, 1999; 2006), orientado por pesquisas efetuadas no litoral baiano (SANTOS; BRANNSTROM, 2015).

O questionário incluiu questões com respostas fixas, Likert e abertas. A escala Likert é um instrumento de observação e aferição dos fenômenos sociais. A elaboração 
de perguntas a partir dessa escala concede aos sujeitos da pesquisa a possibilidade de atribuir níveis de importância as temáticas investigadas (MARCONI; LAKATOS, 2013). A escala Likert fundamenta-se em utilizar um conceito teórico não observável como o amor, medo, raiva, etc. e desenvolver uma somatória de afirmações relacionadas ao tema, para em seguida os respondentes emitirem seu grau de concordância (SILVA JÚNIOR; COSTA, 2014). No Cumbe, a escala foi utilizada buscando identificar os meios de subsistência voltados para o consumo familiar e para o mercado, e o nível de concordância ou discordância dos moradores locais quanto aos impactos dos empreendimentos sobre seus meios de subsistência.

O questionário foi estruturado envolvendo quatro grandes temas: demografia doméstica; impactos da energia eólica e da carcinicultura; ativos e atividades de subsistência e território quilombola. No âmbito das atividades de subsistência, os participantes relataram sobre atividades voltadas para autoconsumo e comércio com seus rendimentos mensais; instrumentos de pesca, de captura de mariscos e de cultivos de alimentos; tipos de embarcações, propriedade dos instrumentos; locais de pesca, de extração e de cultivos; espécies capturadas e cultivadas; porcentagem média mantida para consumo e comercialização; locais de venda e impactos da carcinicultura e do parque eólico sobre as atividades. Os entrevistados relataram a renda de todos os membros da família, destacando-se também atividades realizadas fora do território da comunidade.

Participaram da aplicação do questionário 23 chefes de família residentes na comunidade do Cumbe escolhidos de forma aleatória. O tamanho da amostra inicial era de 35 residentes, baseando-se na quantidade estimada de agregados familiares (168 famílias, segundo a agente de saúde responsável pela população residente no Cumbe). Porém, os conflitos internos advindos do processo de regularização fundiária comprometeram a aplicação da totalidade dos questionários. Ressalta-se que a qualidade dos dados obtidos foi aumentada pelo fato das respostas às perguntas levarem a discussões mais longas com os entrevistados. Estas falas foram gravadas e transcritas. A análise dos dados qualitativos foi efetuada por "coding". Os "codes" foram organizados seguindo os temas do questionário, ajudando assim na interpretação dos dados quantitativos.

Para a coleta de dados, inicialmente foram realizadas duas reuniões com lideranças da Associação Quilombola do Cumbe, para solicitação de autorização para o 
Pluriatividade em uma comunidade pesqueira no litoral Leste do Ceará: estimativas e desdobramentos para a gestão dos recursos ambientais
Leilane Oliveira Chaves Christian Brannstrom Edson Vicente da Silva

desenvolvimento da pesquisa junto à comunidade e ao Comitê de Ética de Pesquisa da Universidade Federal do Ceará (UFC). Os trabalhos de campo ocorreram no período de maio a novembro de 2016, totalizando 11 visitas a comunidade, que intercalaram momentos de observação, atividades de workshops e aplicação de questionários. A metodologia interligou diferentes instrumentos como a observação participante, diário de campo e aplicação de questionários, assegurando assim, a alta confiabilidade dos dados quantitativos e qualitativos obtidos.

\section{Descrição de algumas características da amostragem}

Os respondentes apresentaram uma média de idade de 40,1 anos e o tempo de moradia na comunidade indicou uma certa homogeneidade, com média de 24,5 anos (Tabela 1).

Tabela 1: Características da população amostrada ( $\mathrm{n}=23)$.

\begin{tabular}{l|c|c}
\hline \multicolumn{1}{c|}{ Respondentes } & Média & Mediana \\
\hline Idade & 40,13 & 38 \\
\hline Número de pessoas por domicílio & 3,35 & 3 \\
\hline Grau de instrução do chefe da família & 3,39 & 4 \\
\hline Tempo de moradia na residência & 3,18 & 4 \\
\hline Número de residentes que trabalham & 1,73 & 2 \\
\hline Participação na colônia de pescadores & 1,56 & 6 \\
\hline Quantidade de compartimentos por moradia & 5,57 & $1.200,00$ \\
\hline Renda mensal por família (R\$) & $1.711,09$ & 30,00 \\
\hline Valor da conta de água (mensal) & 38,44 & 65,00 \\
\hline Valor da conta de luz (mensal) & 91,83 & \\
\hline
\end{tabular}

Fonte: Leilane Oliveira Chaves (2017).

Apenas 6 famílias residem na localidade a menos de 5 anos. Dentre os entrevistados a média de residentes por domicílio é de 3,35 pessoas, entre a faixa etária de 1 a 73 anos. Em relação ao grau de escolaridade dos respondentes a média foi de 3,39, o que representa que grande parte dos chefes de família possuem apenas o ensino fundamental incompleto. Das 23 famílias apenas 10 pessoas participam da colônia de pescadores, apresentando uma média de 1,56.

A renda média por entrevistado foi de $\mathrm{R} \$ 1.711,00$, havendo oscilações nos rendimentos mensais como será apresentado nas seções seguintes do presente artigo. Em relação as condições de habitação, das 23 famílias, 18 delas se declaram donas da 
propriedade, mesmo não obtendo a regularização fundiária das terras que ocupam e 3 domicílios são regidos pelo sistema de contrato de aluguel. O sistema de água e esgoto é mantido pela Companhia de Água e Esgoto do Ceará (CAGECE) e os sistema elétrico pela Enel Distribuição (ENEL). Os valores pagos mensalmente apresentam uma média de $\mathrm{R} \$ 38,00$ e $\mathrm{R} \$ 92,00$, respectivamente. Das 23 famílias, apenas 4 informaram possuir poços em sua residência. Entretanto, essa água não é utilizada para consumo doméstico. Seu uso se restringe a irrigação dos cultivos, pois possui uma alta concentração de capa rosa (ferro).

\section{Principais atividades entre o rio e o mar e outros rendimentos}

A pluriatividade é uma prática presente em $96 \%$ dos grupos familiares que integram a pesquisa. Do total de 23 famílias entrevistadas, apenas 1 possui uma única fonte de renda. $\mathrm{O}$ restante dos respondentes está envolvido em mais de uma atividade relacionadas ou não ao uso dos recursos naturais, dentro ou fora do território.

No Gráfico 1 estão representadas as principais atividades e proventos ligados a subsistência doméstica apontados pelos residentes do Cumbe. A mariscagem, a pesca no rio, a criação de animais, os cultivos domésticos, o benefício do Bolsa Família e outros rendimentos foram as categorias que receberam o maior número de indicações. Dentre elas, a mariscagem (16 indicações), pesca no rio (12 indicações) e outros rendimentos (11 indicações), foram as categorias mais representativas para a subsistência doméstica das famílias do Cumbe.

A mariscagem e a pesca no rio apesar de apresentarem inconstâncias na renda mensal das famílias pela dinâmica natural do próprio ambiente, são práticas exercidas pelos moradores há várias gerações. Da mesma forma, a criação de animais (9 indicações) e a horta (6 indicações) embora apresentem um número pequeno de sinalizações simbolizam para as famílias maior autonomia e diversificação de suas fontes alimentares. Como indica o entrevistado 2 (43 anos, 28/10/2016) "nois somo a base dessa [mariscagem] de tudo. Tem dia que eu vou e pego sururu [Mytella charruana], guaiamum [Cardisoma guanhumi], tudo junto. Quando uma falta, a gente sempre complementa com a outra". Na categoria outros rendimentos, das 10 indicações, 4 correspondem a famílias que não realizam mais atividades relacionadas ao uso dos recursos naturais, tendo suas 
Pluriatividade em uma comunidade pesqueira no litoral Leste do Ceará: estimativas e desdobramentos para a gestão dos recursos ambientais
Leilane Oliveira Chaves Christian Brannstrom Edson Vicente da Silva

fontes de renda atreladas a benefícios sociais, ofícios nas fazendas de camarão e no parque eólico, proprietários de pequenos comércios, prestação de serviços a terceiros, dentre outros.

Gráfico 1: Principais rendimentos de subsistência doméstica no Cumbe.

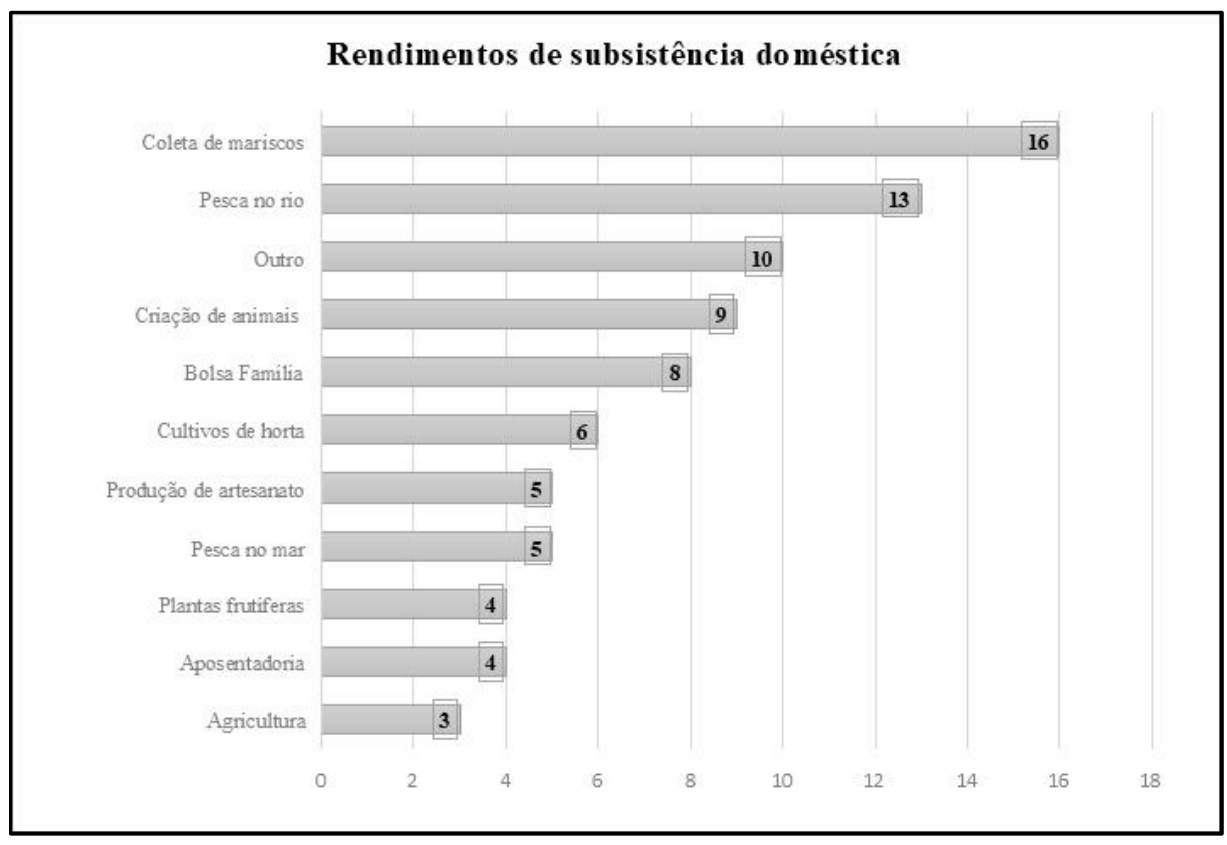

Fonte: Leilane Oliveira Chaves (2017).

A categoria do benefício do Bolsa Família apesar de não ser uma atividade exercida pelas famílias recebeu uma expressiva quantidade de indicações pois, tem representado um aumento de suas rendas através de medidas compensatórias. Para 8 famílias o valor recebido mensalmente é um importante complemento da renda familiar. Como indica a entrevistada 10 (53 anos, 10/09/2016): "é importante porque todo mês eu já tenho esse dinheirinho lá para pagar a minha energia e a minha água, garantido né, nunca atrasou”. Existe uma família como é o caso da entrevistada 8 (52 anos, 29/10/2016) que não exerce outras ocupações e que possui no benefício social a única fonte de renda. A entrevistada informa que "eu só vivo do Bolsa Família. Aqui em casa ninguém pesca mais". As famílias que relataram ter no Bolsa Família uma de suas principais fontes de renda apresentam dificuldades para garantir o sustento de suas famílias.

No tocante ao nível de importância que cada atividade ou rendimento representa para a subsistência doméstica, tem-se a opinião dos grupos familiares, de acordo com a 
escala Likert (Gráfico 2). Ao atribuírem níveis de importância das atividades e rendimentos para a subsistência doméstica, os respondentes indicaram as atividades relacionadas ao uso dos recursos naturais como a coleta de mariscos (16 indicações), pesca no rio (13 indicações), criação de animais (9 indicações) e a horta (6 indicações), como as atividades com maior destaque para a garantia do sustento familiar.

Gráfico 2: Respostas quanto ao nível de importância das atividades e rendimentos domésticas.

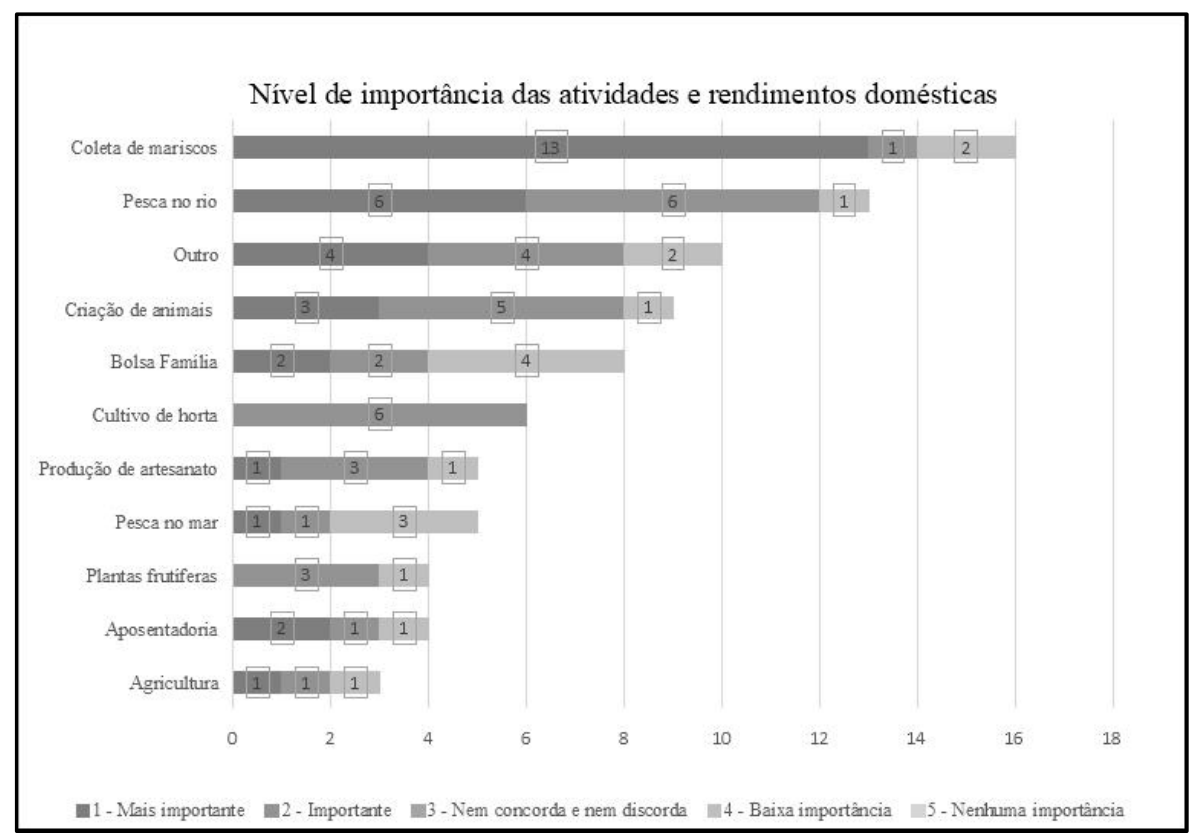

Fonte: Leilane Oliveira Chaves (2017).

A expressiva quantidade de indicações no escore 1 (mais importante) reflete a importância e a grande quantidade de famílias envolvidas com a prática da mariscagem, como indica o entrevistado 2 (43 anos, 28/10/2016): "no inverno prá pesca do caranguejo é mais ruim por causa dos tempos chuvoso, mas mesmo assim é uma atividade que a gente vai. É o ano todim". A redução da disponibilidade de mariscos tanto no rio como no manguezal estão relacionadas aos impactos negativos gerados pela carcinicultura, que ocasionaram a redução no consumo, na comercialização de alguns mariscos e na necessidade de inclusão de novas atividades para a complementação da renda familiar.

A agricultura recebeu apenas 3 indicações, concentrando pontuações no escore 1 (mais importante), 2 (importante) e 4 (baixa importância). A reduzida quantidade de 
indicações é devido à redução de áreas livres para o cultivo, fora das propriedades domiciliares em decorrência da expansão das fazendas de camarão.

A atividade de pesca representa níveis de importância diferenciadas para os grupos familiares. A pesca no rio recebeu seis indicações no escore 1 (mais importante), seis indicações no escore 2 (importante) e uma indicação no escore 4 (baixa importância) e a pesca no mar uma indicação no escore 1 (mais importante), uma indicação no escore 2 (importante) e três indicações no escore 4 (baixa importância). A proximidade entre o núcleo residencial e o rio têm relação direta com os resultados evidenciados no Gráfico 2. A facilidade de se realizar a pesca no rio é maior, não havendo a necessidade da utilização de transporte e de embarcações para chegar aos locais de pesca, favorecendo o envolvimento de um maior número de famílias com essa atividade. Diferentemente da pesca no mar, que é realizada na comunidade a partir da formação de grupos que possuam afinidades entre si. Além disso, a necessidade de uma embarcação e de um veículo automotor para realizar o transporte da rede e dos demais equipamentos distância os moradores dessa atividade.

Apesar das dificuldades devido questões de logística e pelos impedimentos causados pela eólica, a pesca no mar é uma atividade importante para as famílias, principalmente durante o período do inverno onde as atividades de algumas famílias estão mais relacionadas com os pescados oriundos do mar. Como indica o entrevistado 2 (43 anos, 28/10/2016), "eu uso mais no inverno o mar [ $1^{\circ}$ semestre do ano], porque o mangue fica mais ruim no inverno e aí a gente vai pro mar”.

Além das atividades voltadas diretamente para o consumo familiar, os dados também identificaram as atividades voltadas para o mercado. No Gráfico 3, os entrevistados foram indagados acerca das atividades desenvolvidas por suas famílias destinados ao mercado interno e externo à comunidade. Dentre as atividades as famílias destacaram a coleta de mariscos (13 indicações), a pesca no rio (7 indicações) e no mar (6 indicações) e a criação de animais (5 indicações), como as práticas que conseguem gerar excedentes que são utilizados na comercialização. Como pescam um número reduzido de peixes e criam poucos animais, o comércio do excedente não ocorre cotidianamente. Acredita-se que por isso tenha apresentado um número diminuto de sinalizações voltados para o comércio. 
A mariscagem novamente recebeu um maior número de sinalizações, com 13 indicações. Na mariscagem as principais espécies capturadas pelas famílias são o sururu [Mytella charruan], intã [Tatelus plebeus], ostra [Crassostrea gigas] e os caranguejosuça [Ucides cordatus] e guaiamu [Cardisoma guanhumi]. Porém, das indicações expostas há 10 famílias que comercializam apenas o caranguejo e as demais 3 famílias realizam apenas o comércio dos moluscos sururu, intã e ostra.

Gráfico 3: Atividades orientadas ao mercado.

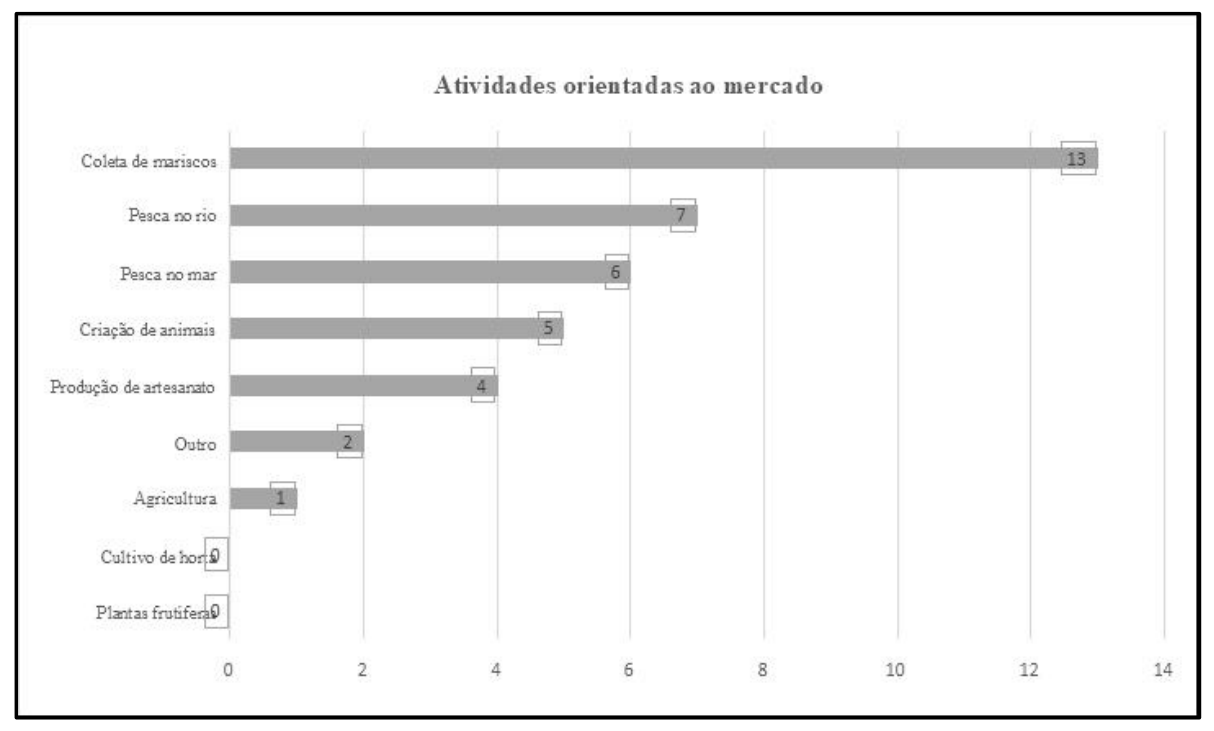

Fonte: Leilane Oliveira Chaves (2017).

A horta e as plantas frutíferas não foram identificadas pelos entrevistados como atividades voltadas para o mercado. Entretanto, no caso das plantas frutíferas alguns entrevistados destacaram que determinadas espécies como a acerola, limão, coco ofertam uma grande quantidade de frutos. A quantidade colhida todo mês supera o consumo das famílias, ocasionando o desperdício de muitos alimentos. Como relata o entrevistado 2 (43 anos, 28/10/2016):

É mais para consumo, na verdade como a comunidade cada um tem sua acerola, seu limão. Então, fica difícil vende. A gente fica mais pra o consumo de casa mesmo. E agora assim, se tivesse quem comprasse né é claro que a gente vendia, porque até mesmo disperdiça muito, acerola, limão, as vezes a gente doa. Todo mundo tem em seus quintais. Se você for andar em vários quintais assim, você vai ver um monte de disperdício de acerola, porque ela carrega muito. Assim, o limão quando ele bota carreia ele bota mais de uma vez. 
Pluriatividade em uma comunidade pesqueira no litoral Leste do Ceará: estimativas e desdobramentos para a gestão dos recursos ambientais
Leilane Oliveira Chaves Christian Brannstrom Edson Vicente da Silva

Ainda de acordo com o entrevistado 2 (43 anos, 28/10/2016) muitas vezes falta conhecimento sobre as formas de utilização de um alimento: "no período do limão o que a gente pode fazer com ele, porque as vezes você não tem nem o conhecimento de outros pratos que possa criar né do limão". Alguns entrevistados destacaram que poderiam destinar uma parte para a comercialização da fruta "in natura" ou através de seu beneficiamento. Doces, geleias e polpas, foram algumas das sugestões expostas pelos moradores. No caso da horta, os limitados espaços destinados ao cultivo de hortaliças e plantas medicinais impossibilitam a expansão da produção.

Gráfico 4: Resposta ao nível de importância das atividades orientadas ao mercado.

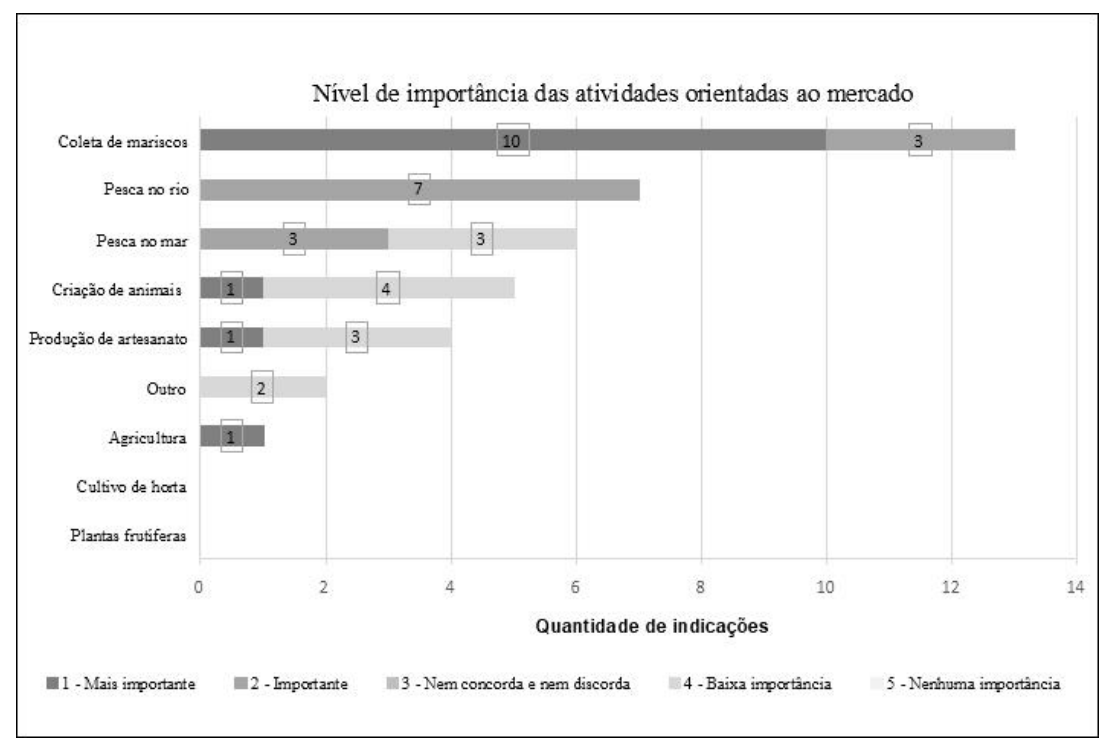

Fonte: Leilane Oliveira Chaves (2017).

Considerando o nível de importância de cada atividade, baseado no mercado, os dados levantados mostraram que a mariscagem obteve as maiores pontuações. No Gráfico 4 a coleta de mariscos concentrou dez indicações no escore 1 (mais importante) e três indicações no escore 2 (importante). Dentre os mariscos capturados o caranguejo é na atualidade o que apresenta os maiores rendimentos mensais. Isso ocorre devido a diminuição da quantidade de ostra, sururu e intã tanto, em área do manguezal como no rio como informa a entrevista 9 (37 anos, 30/10/2016):

Ultimamente a gente não fez mais a mariscagem por falta, porque a gente trabalhava muito com o búzio e naquela época, a gente bem podia se dizer que o sustento da gente vinha todo da pesca. A gente tirava mais ou menos um salário por mês as vezes tirava até mais dependendo 
da maré tava boa, da venda se tava boa e tudo. Hoje em dia como não tem mais o marisco as vezes um peixe que ele pega né.

A pesca no rio recebeu todas as suas indicações no escore 2 (importante). Apesar da representatividade dessa pontuação, quando comparado a atividade de mariscagem, a pesca no rio não apresentou grandes resultados para a comercialização. Segundo relatos de alguns entrevistados, a quantidade de peixes extraídos do rio tem reduzido significativamente conseguindo abastecer apenas as necessidades dos grupos familiares do Cumbe. Entre as famílias que realizam a pesca no mar, 3 delas indicaram que essa atividade é importante (escore 2) e as outras 3 famílias sinalizaram como sendo de baixa importância (escore 4). A quantidade diminuta de indicações da pesca, tanto no mar como no rio, é destacada por alguns entrevistados como uma questão normal do seu cotidiano. Como indica o entrevistado 4 (52 anos, 12/08/2016), "pescaria é loteria e nem sempre você tá ali e não ter nada e pode um dia voltar com 6,7 quilos". No entanto, no caso da pesca no rio as famílias também associam a instalação das fazendas de camarão como uma prática influenciadora na redução dos pescados.

\section{A pluriatividade entre os grupos familiares}

$\mathrm{Na}$ análise da pluriatividade entre os residentes do Cumbe, a pesquisa se baseou no modelo proposto por Sacco dos Anjos, et al. (2012), onde definiu-se como família pluriativa aquela que possui no mínimo um dos seus componentes familiares envolvidos em atividade não-pesqueiras. Aplicando este modelo aos dados obtidos (Quadro 1), identifica-se a inexistência de famílias exclusivamente pesqueiras. Nos dados analisados as famílias até possuem a pesca no rio ou no mar como sua base principal alimentar e econômica, mas a conciliam com pelo menos uma atividade ou com auxílios financeiros (7 famílias). Das 23 famílias entrevistadas, 10 desenvolvem mais de 3 atividades durante o ano, relacionadas a pesca ou não. Já na categoria não pesqueiras, tem-se o total de 9 famílias que não desenvolvem mais atividades associadas a pesca. 
Pluriatividade em uma comunidade pesqueira no litoral Leste do Ceará: estimativas e desdobramentos para a gestão dos recursos ambientais
Leilane Oliveira Chaves Christian Brannstrom Edson Vicente da Silva

Quadro 1: Descrição dos tipos de famílias segundo a condição de atividade, adaptado de Sacco dos Anjos et al. (2005) para a comunidade Cumbe

\begin{tabular}{|c|c|c|c|}
\hline \multirow{2}{*}{\multicolumn{2}{|c|}{$\begin{array}{c}\text { Categorias } \\
\begin{array}{c}\text { Famílias exclusivamente } \\
\text { pesqueiras }\end{array}\end{array}$}} & Descrição & Cumbe \\
\hline & & Dedicação unicamente a pesca & $\begin{array}{l}\text { Pesca no rio e no mar conciliada a } \\
\text { outra atividade }\end{array}$ \\
\hline \multirow[t]{2}{*}{$\begin{array}{l}\text { Famílias } \\
\text { pluriativas }\end{array}$} & $\begin{array}{c}\text { Base } \\
\text { pesqueira }\end{array}$ & $\begin{array}{l}\text { Captura do pescado e outras } \\
\text { atividades relacionadas a pesca } \\
\text { (salga, filetamento } \\
\text { processamento para venda) }\end{array}$ & $\begin{array}{lc}\text { Não se aplica, pois, todas as } \\
\text { famílias realizam } & \text { o } \\
\text { beneficiamento do seu pescado }\end{array}$ \\
\hline & $\begin{array}{l}\text { Base não- } \\
\text { pesqueira }\end{array}$ & $\begin{array}{l}\text { Realizam a pesca e outras } \\
\text { ocupações não relacionadas a } \\
\text { pesca }\end{array}$ & $\begin{array}{l}\text { Pesca, beneficiamento do pescado, } \\
\text { mariscagem, criação de animais, } \\
\text { prestação de serviços e comércio }\end{array}$ \\
\hline \multicolumn{2}{|c|}{ Famílias não pesqueiras } & $\begin{array}{l}\text { Não realizam mais atividades } \\
\text { relacionada a pesca }\end{array}$ & $\begin{array}{l}\text { Benefícios sociais, mariscagem, } \\
\text { criação de animais, prestação de } \\
\text { serviços e comércio }\end{array}$ \\
\hline
\end{tabular}

Fonte: Leilane Oliveira Chaves (2017).

Para exemplificar como a pluriatividade se manifesta no Cumbe, foram selecionadas 6 famílias que apresentaram distinções em suas atividades e rendimentos relevantes para entender a pluriatividade. Na Tabela 2 tem-se a identificação dos entrevistados, com suas respectivas ocupações e rendimentos mensais. Nota-se que a entrevistada 19 (44 anos, 28/10/2016) apresenta apenas uma fonte de renda que advém da prestação de serviços como camareira em uma pousada na sede municipal. O grupo familiar representado pela entrevistada 19 informa que a renda da família é de $\mathrm{R} \$ 880,00$, sendo destinado para o sustento de quatro pessoas. Os demais integrantes da família não realizam nenhuma atividade por serem menores de idade ou por apresentarem problemas de saúde.

Tabela 2: Grupos familiares do Cumbe e as diferenciações em seus rendimentos

\begin{tabular}{|c|c|c|c|c|c|c|c|c|c|c|c|c|}
\hline \multirow{2}{*}{$\begin{array}{l}\text { Grupo } \\
\text { familiar }\end{array}$} & \multirow{2}{*}{$\begin{array}{c}\mathrm{N}^{\circ} \text { de } \\
\text { membros no } \\
\text { domicílio }\end{array}$} & \multicolumn{9}{|c|}{ Atividades e Benefícios* } & \multirow{2}{*}{$\begin{array}{c}\text { Renda } \\
\text { Mensal } \\
1^{\circ} \text { semestre }\end{array}$} & \multirow{2}{*}{$\begin{array}{c}\text { Renda } \\
\text { Mensal } \\
2^{\circ} \text { semestre }\end{array}$} \\
\hline & & 1 & 2 & 3 & 4 & 5 & 6 & 7 & 8 & 9 & & \\
\hline ID 19 & 4 & & & & & & & & & & $\mathrm{R} \$ 880,00$ & $\mathrm{R} \$ 880,00$ \\
\hline ID 8 & 3 & & & & & & & & & & $\mathrm{R} \$ 85,00$ & $\mathrm{R} \$ 185,00$ \\
\hline ID 17 & 5 & & & & & & & & & & $\mathrm{R} \$ 1.080,00$ & $\mathrm{R} \$ 1.080,00$ \\
\hline ID 14 & 2 & & & & & & & & & & $\mathrm{R} \$ 1.200,00$ & $\mathrm{R} \$ 1.200,00$ \\
\hline ID 7 & 5 & & & & & & & & & & $\mathrm{R} \$ 1.000,00$ & $\mathrm{R} \$ 1.000,00$ \\
\hline ID 2 & 5 & & & & & & & & & & $\mathrm{R} \$ 3.435,00$ & $\mathrm{R} \$ 3.035,00$ \\
\hline
\end{tabular}


A entrevistada 8 (52 anos, 29/10/2016) possui duas fontes de renda como pode-se observar na Tabela 2. A mariscagem gera mensalmente um valor de $\mathrm{R} \$ 100,00$ e o benefício do Bolsa Família disponibilizado pelo Governo Federal, um valor mensal de $\mathrm{R} \$ 85,00$. As duas fontes de renda somam um valor total de $\mathrm{R} \$ 185,00$, para o sustento de três pessoas. Todavia, a atividade de mariscagem só é praticada no segundo semestre do ano com a diminuição do período chuvoso. Dessa forma, durante o primeiro semestre do ano, a principal fonte de renda da entrevistada 8 é o Bolsa Família.

A entrevistada 17 (35 anos, 29/10/2016) (Tabela 2) tem o seu rendimento familiar atrelado a comercialização de gêneros alimentícios na comunidade e a prestação de serviços como vigia do parque eólico localizado na comunidade. A pesca ocorre apenas no segundo semestre do ano, quando integrantes do grupo familiar estão de folga de suas atividades primárias. Os peixes capturados são destinados apenas para o consumo familiar. O comércio de alimentos gera um valor mensal de $\mathrm{R} \$ 200,00$ e a ocupação como vigia gera um valor de $\mathrm{R} \$ 880,00$. A renda total da família é de $\mathrm{R} \$ 1.080,00$ para o sustento de cinco pessoas do domicílio.

O entrevistado 14 (34 anos, 10/09/2016) possui todos os seus rendimentos associados ao uso dos recursos naturais (Tabela 2). Com a pesca, o valor gerado mensalmente por ele é de $\mathrm{R} \$ 700,00$. A mariscagem apresenta um rendimento de $\mathrm{R} \$ 500,00$ e o artesanato é confeccionado apenas como um passatempo em momentos de folga do entrevistado, não gerando nenhum rendimento para a família. O valor da renda mensal é de $\mathrm{R} \$ 1.200,00$ para o sustento de duas pessoas, porém tanto a pesca como a mariscagem apresentam uma diminuição nos rendimentos em determinados períodos do ano. O entrevistado 14 realiza a pesca no rio e no mar, por isso consegue ter pescado suficiente para comercializar durante o ano inteiro, já a captura do caranguejo ocorre com maior intensidade no segundo semestre do ano.

O grupo familiar representado pela entrevistada 7 (19 anos, 10/09/2016) obtém cinco fontes diferenciadas para o sustento de sua família, garantindo uma maior estabilidade alimentar e financeira. A agricultura, mariscagem, horta, criação de animais e o benefício do Bolsa Família integram as fontes de renda desse núcleo familiar. Com a agricultura e a mariscagem o valor obtido mensalmente é de $\mathrm{R} \$ 500,00$ cada, a horta é direcionada apenas para o consumo familiar. Na criação de animais (galinhas e ovelhas) 
a entrevistada não soube mensurar quanto consegue gerar mensalmente, pois a venda ocorre em diferentes momentos do mês. O rendimento mensal de $R \$ 1.000,00$ e a produção de autoconsumo são para o sustento de cinco pessoas.

O entrevistado 2 (43 anos, 28/10/2016) corresponde ao grupo familiar que apresenta a maior diversidade de atividades, possuindo sete diferentes fontes de renda e de autoconsumo. A família desenvolve a pesca no rio e no mar, a mariscagem, cultivam hortaliças e árvores frutíferas, criam ovelhas e galinhas, prestam serviços na construção de barracas de praia e como auxiliares em serviços de entretenimento em Canoa Quebrada (um local turístico aproximadamente 1,7 km de distância), além disso, são contemplados com o benefício do Bolsa Família.

No grupo familiar representado pelo entrevistado 2, a horta é utilizada apenas para o consumo familiar. A pesca no rio é realizada o ano inteiro, com um rendimento mensal de $R \$ 450,00$. No mar a pesca gera um valor de $R \$ 200,00$, sendo realizada apenas no período chuvoso. A mariscagem em especial a captura do caranguejo ocorre o ano inteiro assegurando um valor total de $\mathrm{R} \$ 1.200,00$. Todavia, de acordo com a espécie esse rendimento tem uma variação. O caranguejo-uça é capturado o ano inteiro gerando um rendimento de $\mathrm{R} \$ 1.000,00$ mensais, já o caranguejo guaiamum é capturado apenas no período chuvoso com um rendimento de $\mathrm{R} \$ 200,00$. A construção de barracas gera um valor de $\mathrm{R} \$ 400,00$, porém essa atividade não é realizada mensalmente, mas em alguns períodos do ano. Outra atividade externa a comunidade desenvolvida por essa família, é como funcionário de um serviço de entretenimento em Canoa Quebrada, essa atividade gera mensalmente um valor de $\mathrm{R} \$ 1.500,00$.

Para o entrevistado 2, os rendimentos gerados com a construção de barracas e com a criação de animais é de difícil mensuração, pois são atividades realizadas com menor frequência. Dessa forma, optou-se por não incluir o valor desses rendimentos na Tabela 2 já que o entrevistado não sabia informar em qual época do ano essas atividades tinham um rendimento mais significativo. $\mathrm{O}$ valor dos rendimentos e as fontes de autoconsumo proporcionam o sustento de cinco pessoas.

$\mathrm{Na}$ Tabela 2, observa-se uma variação de rendimentos e de atividades entre os grupos familiares. Todavia, é importante ressaltar que algumas dessas atividades não ocorrem o ano todo e nem ao mesmo tempo. Como exemplo a pesca no rio e no mar não 
são realizadas ao mesmo, sendo a primeira realizada com maior frequência no segundo semestre do ano e a segundo no primeiro semestre por causa das condições ambientais. A diferenciação de renda entre as famílias está muito mais relacionada a quantidade de atividades desenvolvidas e o retorno financeiro ou de autoconsumo que se obtém com cada uma delas, do que com a quantidade de membros que compõem o domicílio. Por exemplo, pode-se analisar a entrevistada 8 , que apresentou uma renda mensal que se alterna de $\mathrm{R} \$ 85,00$ a $\mathrm{R} \$ 185,00$. Além do benefício social essa família trabalha com a mariscagem no segundo semestre do ano. Ao passo que o entrevistado 2 possui uma renda que pode variar de $\mathrm{R} \$ 3.435,00$ a $\mathrm{R} \$ 3.035,00$ e que além do Bolsa Família, desenvolve mais seis atividades distribuídas ao longo do ano assegurando estabilidade na subsistência familiar e ampliando as fontes e formas de acesso a renda.

A quantidade de membros por família no caso do Cumbe não vai ser condição para se afirmar a tendência a pluriatividade, já que há famílias constituídas por 2 pessoas realizando até três diferentes atividades e famílias com 4 componentes realizando apenas duas atividades. Já a idade se mostrou ser um limitador da pluriatividade se o membro do grupo familiar já tiver uma idade avançada ou apresentar problemas de saúde. Os resultados obtidos não permitem afirmar que a existência de múltiplas atividades esteja relacionada a quantidade de mão de obra disponível, mas que a pluriatividade vai se manifestar independentemente da quantidade de membros familiares e que influenciará na independência financeira e alimentar das famílias.

Acredita-se que diversos motivos levam as pessoas ou grupos familiares a diversificarem suas atividades. Uma das justificativas é a garantia de mais opções de produtos para comercialização e autoconsumo, reduzindo os riscos e vulnerabilidades do agregado domiciliar. No caso do Cumbe, a combinação de atividades envolve muitas variáveis como a proatividade da família, o conhecimento que possuem do seu território, a disponibilidade de tempo que podem empreender com outras atividades, a quantidade de residentes no núcleo familiar em condições de exercer uma nova atividade, e principalmente pelo cerceamento da manutenção das atividades que desenvolviam referente a pesca e mariscagem, etc. Essas variáveis influenciam a forma como as famílias se inserem ou não nas novas ocupações em seu cotidiano. 
A diversificação de atividades demostra o conhecimento que os grupos locais possuem do seu território e das condições dos recursos naturais que integram esse mesmo território. Nos relatos dos entrevistados observa-se que as diferentes práticas exercidas pelas famílias ocorrem respeitando a dinâmica de cada ambiente. "Eu não sei muito a história do mar, mas eu acho que o mar é quase a mesma história daqui [rio]" (entrevistada 9, 37 anos, 30/10/2016); "No mar né a gente tem período" (entrevistado 2, 43 anos, 28/10/2016); “A gente ia por maré" (entrevistada 4, 52 anos, 12/08/2016); "Fica mais dentro d’água não fica no seco. Ele [peixe] não se dá. Tem que ser em baixo da água" (entrevistado 14, 34 anos, 10/09/2016); "Em maio começa a cata do caranguejo, nos chama a safra do caranguejo" (entrevistado 16, 33 anos, 12/08/2016). Esses são apenas alguns relatos acerca do conhecimento dos residentes sobre o seu território e que tem permitido que essas famílias estabelessam uma diversidade de ocupações ao longo do ano.

\section{Renda geradas pelas atividades}

Ao analisar a renda gerada por cada atividade, os dados mostraram que os maiores rendimentos estão associados a atividades que não estão relacionadas ao uso dos recursos naturais, como indica o entrevistado 4 (52 anos, 12/08/2016), "sinceramente a renda que nois deixa hoje aqui, que deixa a gente mais preparado digamos assim, é o emprego mesmo". Como se observa no Gráfico 5, os valores gerados pela categoria "outras atividades" possibilita que as famílias obtenham um valor mensal superior aos rendimentos alcançados com suas atividades tradicionais. Isso contribui, para que cada vez mais, um número maior de famílias insira em seu cotidiano novas fonte de renda. Porém, é importante evidenciar que a inserção de novas atividades e rendimentos ocorre diante de um cenário de cerceamento ao uso dos recursos naturais de forma plena como ocorria antes da instalação dos empreendimentos.

No relato do entrevistado 2 (43 anos, 28/10/2016), o morador relata as limitações que tem vivenciado após a instalação de fazendas de camarão: "a carcinicultura proibiu mais. É cerca por todo o canto aí. Porque a gente ia por aqui e a gente ia bater lá na boca da barra, hoje você não vai. Cerca direto, e depois mais cerca, passa outra, passa outra, menino". De acordo com o entrevistado 16 (33 anos, 12/08/2016), as limitações geradas 
Pluriatividade em uma comunidade pesqueira no litoral Leste do Ceará: estimativas e desdobramentos para a gestão dos recursos ambientais
Leilane Oliveira Chaves Christian Brannstrom Edson Vicente da Silva

pela carcinicultura extrapolam as dimensões do território do Cumbe, o entrevistado expõe que "a carcinicultura, muito mais que a eólica. Você pode subir aqui o Jaguaribe da nascente a foz você só vai ver limitação". Para algumas famílias as limitações geradas pelos dois empreendimentos possuem a mesma intensidade já que ambos geram restrições no uso do território. Como aponta a entrevistada 9 (37 anos, 30/10/2016):

\begin{abstract}
"Os dois [parque eólico e carcinicultura] eu acho que tá numa balança super balanceada, porque aqui como a carcinicultura foi construída como a gente chama na parte de baixo, na parte onde a gente mora né ela nos limitou aqui na parte de baixo na parte de rio, na parte de vajada [manguezal - salgado] nos limitou completamente. A carcinicultura nos cerca na parte do rio e do mangue e a eólica nos limita na parte da praia, nas lagoas. Nos caminhos tem muitas limitações quer dizer, em cima das dunas e em baixo. Então eu vejo uma limitação quase que igual".
\end{abstract}

Gráfico 5: Diferenciação dos rendimentos entre as atividades habituais e outras ocupações.

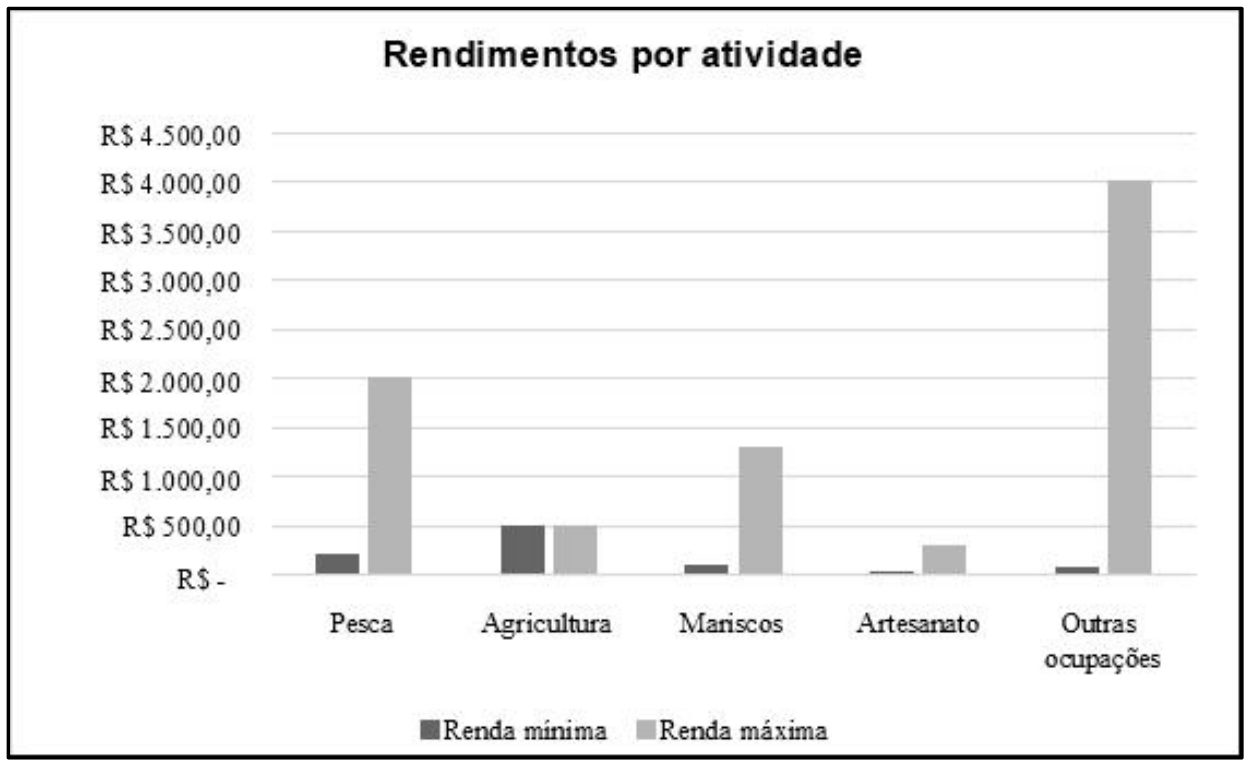

Fonte: Leilane Oliveira Chaves (2017).

No Gráfico 5, consta os menores e maiores rendimentos mensais em relação as atividades praticadas. A pesca e a mariscagem mensalmente chegam a atingir um valor máximo de $\mathrm{R} \$ 1.500,00$. As outras ocupações geram um valor máximo de até $\mathrm{R} \$ 4.000,00$ por mês. Esses valores revelam os baixos rendimentos que as atividades tradicionais em alguns meses do ano proporcionam aos moradores do Cumbe. Porém, apesar dos baixos rendimentos mensais quando comparado a outras ocupações, alguns entrevistados 
destacam que as atividades desenvolvidas por sua família representam e simbolizam o modo de vida da comunidade. Como indica a entrevistada 11 (55 anos, 10/09/2016):

Pesca de siri e jerere. Ficava alegre. Pesquei muito mais meu pai, pesquei muito mais ele. Ele gostava muito de pescar. As vezes quando eu era mais jovem. Assim, como você eu me assubia [subia] nos pé de mangue e ficava lá. Fazia de conta que era um sobrado né, um sobrado subia lá em cima. Era muito importante. Eu amo o mangue.

Outra questão que se destaca é que famílias que possuem seus rendimentos atrelados exclusivamente a outras ocupações, principalmente ocupando cargos nas fazendas de camarão e no parque eólico apresentaram uma maior dependência em relação a essa única fonte de renda, e até mesmo o abandono de práticas que poderiam garantir fontes de autoconsumo. A entrevistada 9 (37 anos, 30/10/2016) relata que quando ocorrem oscilações na produção do camarão, os empreendedores demitem grande parte dos funcionários. Ela relata que:

Tem uma época que eles dão emprego e tem uma época que eles não querem mais. A carcinicultura tá num constante hora ela gera muito emprego ora ele não dá. Nois já passemo por 2 momentos desse que foram completamente secos esvaziados e que não dá mais emprego a ninguém e que os tanques fica aí abandonado e tem hora que eles voltam com tudo e diz pra todo mundo que é muito bom. O primeiro baque [queda na produção] que eles têm joga logo os trabalhadores pra fora.

Outro entrevistado indica que quando os funcionários são desligados das suas ocupações nos empreendimentos retornam para as antigas atividades, como indica o entrevistado 2 (43 anos, 28/10/2016): "quando sai desse emprego [fazendas de camarão] é o mangue que abraça né”. As demissões também ocorrem no parque eólico, mas com menores oscilações se comparado a carcinicultura. No relato do entrevistado 4 (52 anos, 12/08/2016), o morador expõe que por sete anos esteve vinculado ao projeto eólico e que em 2016 juntamente com o seu filho foi desligado de suas ocupações. O entrevistado está tentando se inserir nas atividades que desenvolvia antes, como a criação de animais e a pesca no rio. Como ele mesmo indica no relato a seguir:

A renda atual aqui na casa só tem a renda de uma pessoa que eu trabalhava no parque eólico, nois dois trabalhávamos, quer dizer nois três e dois desempregamo. Agora que eu to desempregado. Eu to em casa cuidando das coisas. No caso da minha família que a gente tá 
falando eu comecei a trabalhar no início do parque eólico se desempreguei esse tempo agora no mês passado eu trabalhei direto com eles aí. Então, nesses 7 anos consecutivo, então nesses 7 anos consecutivo é claro que aqui [atividades tradicionais] ficou um pouco pra trás né, porque eu tava com uma renda direta ligada em outra situação.

A realização de atividades não relacionadas ao uso dos recursos naturais se tornou uma prática comum em pelos menos metade das famílias entrevistadas. Dentre os 23 entrevistados 10, famílias já realizam atividades que não se associam ao uso dos recursos naturais e 4 residentes já consideram essas atividades como suas principais fontes de renda.

\section{Deslocamentos espaciais das atividades}

O deslocamento espacial de atividades no Cumbe ocorre tanto em decorrência dos impactos gerados pelos empreendimentos como pelo fato das práticas locais gerarem fontes de renda e de autoconsumo insuficientes, o que evidência a existência da pluriatividade como uma necessidade e não como uma atitude proativa das famílias. Essa realidade nos permite compreender que a existência da pluriatividade em um determinado grupo pode ser compreendida como um reflexo das condições que o território proporciona aos grupos familiares. No caso do Cumbe, além das características particulares de cada ambiente a instalação de fazendas de camarão e do parque eólico colaboraram para deslocamentos espaciais de determinadas práticas, favorecendo na construção de dois cenários em relação as atividades desenvolvidas.

O primeiro, refere-se a busca de novos locais para continuarem exercendo as mesmas atividades. Com a instalação dos empreendimentos houveram proibições e destruições de locais de pesca, de cultivo, de extrativismo vegetal e de captura de mariscos. A impossibilidade de praticarem suas atividades tradicionais forçou os residentes a deslocarem suas atividades para outras áreas dentro ou fora do território da comunidade. Como exemplo, uma das famílias entrevistadas ao ser questionada se a instalação do parque eólico impactou na confecção do artesanato, a mesma informou que não sofreu impacto em sua produção, pois dentro da comunidade haviam outros espaços 
de extração da madeira, matéria prima, base para a produção do artesanato local que não estavam sob influência do parque eólico.

A mariscagem também passou por um processo de deslocamento para outros setores dentro do rio e do manguezal e até para localidades externas ao território em função da estrutura utilizada para a construção das fazendas de camarão que ocupam importantes espaços do núcleo residencial e de algumas áreas do manguezal e do rio. No caso do sururu, intã e da ostra, os entrevistados ressaltaram que os rejeitos da produção do camarão em cativeiro lançados no rio e no manguezal sem tratamento estão impactando na qualidade da água levando a mortandade, redução e desaparecimento de algumas espécies obrigando os residentes a se transferirem para outros pontos de coleta. Segundo a entrevistada 9 (37 anos, 30/10/2016) e o entrevistado 2 (43 anos, 28/10/2016), a coleta de mariscos, em especial, do caranguejo, a partir de 2016 ocorre também em localidades externas a comunidade. As famílias que possuem embarcações relatam que chegam a se deslocar cerca de $24 \mathrm{~km}$ para outros municípios como Itaiçaba para a captura do sururu e cerca de $371 \mathrm{~km}$ para o estado do Rio Grande do Norte para a captura do caranguejo.

A edificação das fazendas de cultivo de camarão próximos ao manguezal e ao rio tem alterado os caminhos que os moradores realizavam para chegarem aos pontos de coleta dentro do território. Como não possuem embarcações, os percursos se tornaram mais longos pela presença de cercas e muitas mulheres já não estão mais se envolvendo com essa atividade pelas dificuldades de acesso aos locais de extração.

O segundo cenário diz respeito ao deslocamento de alguns residentes para outras atividades relacionadas ou não ao uso dos recursos naturais dentro ou fora do núcleo comunitário. Alguns residentes conseguiram ocupações nos empreendimentos edificados dentro da comunidade. No caso do parque eólico, os empregos gerados ocorreram em maior quantidade no início da construção do parque. A carcinicultura apesar de oferecer ocupações temporários em função das dificuldades no cultivo pela presença de doenças na produção, há uma grande quantidade de funcionários empregados se comprado ao parque eólico.

A inserção de alguns moradores como funcionários dos empreendimentos influenciou no abandono de atividades tradicionais que garantiam a autonomia das 
famílias. O deslocamento de ocupações coloca os moradores em um estado de dependência dos rendimentos advindos do parque eólico e da carcinicultura. Até mesmo as práticas de autoconsumo estão sendo abandonadas pela falta de tempo para se dedicarem a tais atividades. Entretanto, um residente alegou que os deslocamentos para outras atividades ocorrem não só pelos impactos gerados pelos empreendimentos, mas também, porque as práticas habituais da comunidade são insuficientes para a manutenção do seu núcleo familiar. O entrevistado 4 (52 anos, 12/08/2016) não soube mencionar a partir de que período identificou que somente as atividades tradicionais se tornaram ínfimas para o sustento da sua família. Porém, é importante evidenciar que só deixou de praticá-las quando se tornou funcionário do parque eólico em 2008 e que ao ser demitido voltou a exercer essas atividades.

Para esse entrevistado durante o período que esteve empregado as práticas locais eram apenas fontes complementares, tendo na sua ocupação formal (registrada na carteira de trabalho) a sua principal fonte de renda. Ele destaca que o seu núcleo residencial só realiza atividades como pesca e a mariscagem quando não estão trabalhando formalmente em outras ocupações:

[...] eu não sou um ativo direto nisso aqui [pesca e captura do caranguejo] a gente vai procurar no caso de tá sem emprego. Então você vai ter que procurar uma atividade se você tá sem emprego pra não colocar no mercantil todo dinheiro, porque aí chega no fim do mês dá problema. Aí se parte pra uma pescaria um caranguejo (Entrevistado 4, 52 anos, 12/08/2016).

A entrevistada 17 (35 anos, 29/10/2016) informa que seu cônjuge gostaria de viver apenas da pesca, mas por causa dos baixos rendimentos ele pesca apenas nos momentos de folga. Segundo ela, "se ele pudesse todo dia ele ia pescar. Ele só vai uma vez, quando tá livre". Para essas duas famílias a inconstância das atividades tradicionais favorece que residentes do Cumbe incorporem em seu cotidiano novas atividades não relacionadas ao uso dos recursos naturais. Já para a entrevistada 9 (37 anos, 30/10/2016), os rendimentos advindos das atividades exercidas por sua família são responsáveis pelo seu sustento, pela construção de sua residência e pela aquisição dos demais bens materiais que conseguiu adquirir ao longo dos anos. Ela informa que: 
"Ela [mariscagem] é muito importante pra mim. O búzio tem um papel fundamental, porque eu construí minha casa com a pesca eu e meu marido. Junto nois construímos nossa casa tirando búzio né. Tudo que a gente começou aqui hoje não tá forte como eu to dizendo, mas o que a gente tem, começou aqui a construir veio toda do búzio. Antigamente eu não tinha o comércio a gente vivia exclusivamente desse marisco aqui né. Eu construí casa, eu consegui alguns móveis pra minha casa. Eu me alimentava todo dia né, então pra mim o búzio tem um significado muito forte na minha renda da minha casa".

A dinâmica natural de cada ambiente interfere na constância das atividades praticadas. Muitas ocupações não são desenvolvidas o ano inteiro, ocasionando a oscilação dos rendimentos e da disponibilidade de alimentos. Essa sistuação se tornou ainda mais grave com os impactos dos empreendimentos já que algumas áreas do território já não podem ser mais usadas pelas famílias.

\section{Discussão}

A pluriatividade praticada pelos residentes do Cumbe se relaciona diretamente com os recursos naturais, haja vista os vínculos construídos ao longo de várias gerações e que garantem a continuação sociocultural e econômica da comunidade. A pesca, mariscagem, criação de animais, pequenos cultivos e a confecção de artesanato integram as principais atividades de grande parte dos entrevistados. Da terra ao mar, se encontram práticas que garantem fontes de renda e de autoconsumo para as famílias, frequentemente suplementado por recursos financeiros da Bolsa Família e aposentadorias.

Há uma grande variedade de atividades desenvolvidas pelos grupos familiares, tanto em atividades vinculadas a pesca como em outras ocupações. Porém, ressalta-se que a comercialização dos remanescentes da pesca e da extração, não é uma prática recorrente entre as famílias. Como compartilham os resultados de sua atividade entre os membros da família, a comercialização ocorre quase como último recurso.

Os resultados apresentados aqui, se assemelham aos evidenciados por Sacco dos Anjos, et al. (2012) nos seguintes elementos: diminuição de disponibilidade e diversidade do pescado, principalmente, após a chegada de agentes externos; crescente inserção de atividades não pesqueiras entre os grupos familiares; menores rendimentos presentes em famílias que obtém sua renda apenas por intermédio de atividades ligadas aos recursos 
naturais e benefícios sociais como aposentadoria, pensão e Bolsa Família como rendimentos significativos que asseguram uma garantia de sustento para as famílias. Diferentemente dos estudos de Santos (2015) e Santos e Brannstrom (2015), não se observa no Cumbe o desenvolvimento de atividades terrestres, principalmente em decorrência da expansão das fazendas de camarão que limitaram os espaços para o desenvolvimento de cultivos e criação de animais. Não se alcançou um número de questionários suficiente para estatisticamente classificar os tipos de usuários dos recursos naturais, porém, observa-se uma diferenciação qualitativa entre as famílias.

Apesar de identificar uma diversidade de ocupações entre os grupos familiares do Cumbe, ainda existem residentes que por limitações físicas, problemas de saúde ou idade avançada sobrevivem com apenas uma fonte de renda, enquanto outras famílias conseguem obter até sete tipos de rendimentos diferenciados. Algumas famílias que diversificam seus rendimentos e fontes de autoconsumo destacam que as atividades diretamente relacionadas aos recursos naturais são insuficientes, em especial, devido a instalação das fazendas de camarão e do parque eólico.

Os dados obtidos em campo também permitiram analisar os diferentes tipos de rendimentos e fontes de autoconsumo a partir de dois pontos de vistas. $\mathrm{O}$ primeiro deles é a de que a diversidade de atividades pode originar rendimentos complementares ou fontes diferenciadas de autoconsumo, uma vez que a pluriatividade não se relaciona apenas aos plurirrendimentos, mas também integra as fontes que proporcionam a subsistência do próprio produtor ou núcleo familiar. As famílias que realizam uma maior diversidade de atividades no Cumbe apresentam maiores rendimentos mensais e maior estabilidade financeira e alimentar mesmo após os impactos dos empreendimentos, porém, a amostragem não permite estimativas de correlação estatística. Ademais, para a gestão dos recursos naturais, um maior esforço deve ser lançado nesses ambientes, já que garantem a sobrevivência das famílias.

O segundo aspecto diz respeito a necessidade de se realizar diversas atividades pelo mesmo núcleo familiar. Nos relatos dos entrevistados, a fato de realizarem múltiplas ocupações estava relacionado para algumas famílias com a incapacidade de subsistência que uma única atividade proporcionava ao seu grupo familiar. Para estas famílias, a pluriatividade é uma questão de necessidade e não de escolha. Já para outras famílias, 
apesar de reconhecerem que em alguns períodos do ano suas atividades tradicionais sofrem oscilações, entendem que a prática de diversas atividades em seu cotidiano ocorre pelo acesso a recursos naturais diferentes. Essas famílias acreditam que cada recurso natural possui sua própria dinâmica. E que buscam conduzir seu modo de vida respeitando essa dinâmica. Apesar do pensamento otimista de alguns entrevistados, este cenário reflete a fragilidade das famílias que limitam suas fontes de renda e de autoconsumo a atividades tradicionais, principalmente quando os ambientes explorados são impactados por ações externas influenciando negativamente na insustentabilidade comunitária como é o caso dos residentes do Cumbe, que buscam garantir condições mínimas de existência, sejam elas direta, indiretamente, ou totalmente desvinculadas dos recursos naturais.

\section{Considerações Finais}

Apesar da pluriatividade não ser uma realidade de todas as famílias que integram uma comunidade rural ou litorânea, identificou-se que existe uma maior estabilidade financeira e alimentar nos grupos que diversificam suas fontes de renda, quer elas sejam relacionadas a práticas tradicionais ou não. Como alerta Ellis (1999), a pluriatividade pode ampliar as escolhas e opções de atividades diminuindo a dependência das populações locais a recursos controlados por agentes externos.

As famílias pesquisadas não estão envolvidas apenas em uma única atividade o ano inteiro, mas ocorre uma redução na intensidade praticada ou diminuição na variedade de atividades exercidas pelos membros familiares, ou seja, não há uma temporalidade definida para que as atividades ocorram. As estações do ano por exemplo, apresentam grande relevância na forma como os moradores regem suas atividades durante o ano.

Durante a aplicação dos questionários obtiveram-se duas observações que merecem estudos futuros. Primeiro, observou-se que algumas famílias conseguem diversificar suas atividades em decorrência do conhecimento que o indivíduo possui do ambiente onde reside. Esse tipo de conhecimento manifesta-se no cotidiano das famílias refletidos em suas diversas formas de uso e apropriação dos recursos naturais (ARRUDA, 1999). Esses conhecimentos são na essência, resultado de adaptações ao ambiente onde vivem (REYES-GARCÍA, 2007). Em segundo lugar, identificou-se que o conhecimento 
que obtinham do seu território possibilitou que desenvolvessem estratégias de adaptação e/ou modificação de suas atividades nos espaços impactados por esses empreendimentos.

A pluriatividade pode ser um dos motivos ou fatores que explicam porque não há um maior grau de resistência ao parque eólico instalado nos campos de dunas, já que as famílias teriam outras áreas para continuar utilizando como formas de sustento, diferentemente da carcinicultura que compromete as principais formas de sustento da comunidade, a coleta de mariscos e a pesca no rio. Acredita-se que a intensificação na produção e expansão das fazendas de camarão teriam uma influência direta na pluriatividade, pois as famílias teriam que continuar diversificando suas atividades, mesmo não sendo uma questão de escolha, mas sim por necessidade. $\mathrm{O}$ crescimento dessa atividade também poderia ocasionar uma maior contaminação do ambiente aquático pelos rejeitos da produção lançados a céu aberto e pela ausência de fiscalização dos órgãos ambientais do Estado. A insuficiência de renda poderia ocasionar o aumento de registrados em empregos formais, distanciando os moradores da comunidade de suas práticas habituais e consequentemente enfraquecendo as relações comunitárias. Já a expansão do parque eólico significaria a manutenção dos conflitos pelo acesso ao campo de dunas e ao mar e até uma maior morosidade no processo de titulação das terras que a comunidade pleiteia junto ao INCRA.

\section{Agradecimentos}

O texto resulta da pesquisa de doutorado da primeira autora, realizada com apoio da Coordenação de Aperfeiçoamento de Pessoal de Nível Superior, Capes, Brasil.

\section{Referências}

ARRUDA, R. "Populações tradicionais" e a proteção dos recursos em unidades de conservação. Ambiente \& Sociedade, São Paulo, n. 5, $2^{\circ}$ sem. 1999, p. 79-92.

BEBBingTON, A. Capitals and Capabilities: A Framework for Analyzing Peasant Viability, Rural Livelihoods and Poverty. World Development, Amsterdã, n. 12, v. 27, Dez. 1999, p. 2021-2044.

BEBBINGTON, A.; et al. Local capacity, village governance, and the political economy of rural development in Indonesia. World Development, Amsterdã, n, 11, v. 34, 2006, p. 1958-1976. 
BRANNSTROM, C.; et al. Is Brazilian wind power development sustainable? Insights from a review of conflicts in Ceará state. Renewable and Sustainable Energy Reviews, Amsterdã, v. 67, 2017, p. 62-71.

BROWN, K. B. Wind power in northeastern Brazil: Local burdens, regional benefits and growing opposition. Climate and Development, Reino Unido, v. 3, n. 4, 2011, p. 344360 .

CHAVES, L. O.; Brannstrom, C.; Da Silva, E. V. Energia eólica e a criação de conflitos: ocupação dos espaços de lazer em uma comunidade no Nordeste do Brasil. Sociedade e Território, Natal, v. 29, n. 2, 2018, p. 49-69.

COTRIM, D. S.; MIGUEL, L. de A. Pluriatividade: uma noção aplicável em pescadores artesanais? In: IV ENCONTRO DE ECONOMIA GAÚCHA, 2008, Porto Alegre. Anais do IV Encontro de Economia Gaúcha, Porto Alegre: Fundação de Economia e Estatística, 2008, p. 1-16.

DFID, U. K. Sustainable livelihoods guidance sheets. DFID, London, 1999.

ELLIS, F. Rural livelihood diversity in developing countries: evidence and policy implications. ODI, Londres, n. 40, Abr.1999.

LEROY, J. P.; MEIRELES, A. J. A. Povos indígenas e comunidades tradicionais: os visados territórios dos invisíveis. In: PORTO, M. F.; PACHECO, T.; LEROY, J. P (Org). Injustiça ambiental e saúde no Brasil: o mapa de conflitos. FIOCRUZ: Rio de Janeiro, 2013. p. 115-122.

MARCONI, M. A.; LAKATOS, E. M. Técnicas de pesquisa. São Paulo: Atlas, 2013.

PERONDI, M. A.; SCHNEIDER, S. Bases teóricas da abordagem de diversificação dos meios de vida. Redes, Santa Cruz do Sul, v, 17, n. 2, 2012, p. 117-135.

QUEIROZ, L.; et al. Shrimp aquaculture in the federal state of Ceará, 1970-2012: Trends after mangrove forest privatization in Brazil. Ocean \& Coastal Management, Augustinusga, v. 73, 2013, p. 54-62.

REYES-GARCÍA, V.; SANZ, N. M. Etnoecología: punto de encuentro entre naturaliza y cultura. Ecossistemas, Espanha, v. 16, n. 3, 2007, p. 46-55.

RUA, J. Globalização, desenvolvimento e espaço rural: algumas reflexões sobre o estado do Rio de Janeiro. Geo UERJ Revista do Departamento de Geografia, Rio de Janeiro, n.14, $2^{\circ}$ sem. 2003, p. 19-30.

SACCO DOS ANJOS, F., NIEDERLE, P. A., CALDAS, N. V. Pluratividade e Pesca Artesanal: O Caso da Colônia Z-3 em Pelotas, RS. Sociedade em Debate, Pelotas, v. 10, n. 3, 2012, p. 9-42.

SANTOS, A. N.; BRANNSTROM, C. Livelihood strategies in a marine extractive 
reserve: Implications for conservation interventions. Marine Policy, Amsterdã, v. 59, 2015, p. 44-52.

SANTOS, A. N. Fisheries as a way of life: Gendered livelihoods, identities and perspectives of artisanal fisheries in eastern Brazil. Marine Policy, Amsterdã, v. 62, 2015, p. 279-288.

SCHNEIDER, S. A importância da pluriatividade para as políticas públicas no Brasil. Revista de política Agrícola, Brasília, v. 16, n. 3, 2007, p. 14-33.

SCHNEIDER, S. A pluriatividade na agricultura familiar. Rio Grande do Sul: UFRGS, 2003. 250 p.

SILVA JÚNIOR, S. D. da; COSTA, F. J. Mensuração e Escalas de Verificação: uma Análise Comparativa das Escalas de Likert e Phrase Completion. PMKT. Revista Brasileira de Pesquisas de Marketing, Opinião e Mídia, São Paulo, v. 15, 2014, p. 116.

TERNOSKI, S.; PERONDI, M. Â. As estratégias de diversificação dos meios de vida e a formação da renda: uma análise empírica sobre os estabelecimentos agrícolas familiares cooperados da Cresol. Teoria e Evidência Econômica, Passo Fundo, v. 20, n. 43, 2014, p. 283-312.

VADJUNEC, J. M.; RADEL, C.; TURNER, I. I. B. L. Introduction: the continued importance of smallholders today. Land, v. 5, n. 34, 2016, p. 1-12.

Recebido em 13/03/2019.

Aceito para publicação em 18/08/2019. 